\title{
Constraint and Suggestion Analysis in Production and Marketing of Maize in Marathwada Region of Maharashtra using Garrett's Ranking Technique
}

\author{
R. F. Thombre", K. V. Deshmukh, S. S. More and R. V. Chavan \\ Department of Agricultural Economics, College of Agriculture Parbhani, \\ VNMKV, Parbhani-431 402 (MS), India \\ *Corresponding author
}

\section{A B S T R A C T}

\begin{tabular}{|c|}
\hline Keywords \\
\hline $\begin{array}{l}\text { Production and } \\
\text { Marketing of } \\
\text { Maize, Garrett's } \\
\text { Ranking Technique }\end{array}$ \\
\hline Article Info \\
\hline $\begin{array}{l}\text { Accepted: } \\
18 \text { July } 2020 \\
\text { Available Online: } \\
10 \text { August } 2020\end{array}$ \\
\hline
\end{tabular}

The present investigation was undertaken with a view to study the constraints faced by the maize growers in production and marketing of maize in Marathwada Region of Maharashtra. Multiple responses taken to ascertain the constraints faced by the maize growers in production and marketing of maize. Opinion of selected maize growers was taken in order to understand the problems in production and marketing. Thus suggestions of maize growers were recorded and analyzed. Garrett's ranking technique was employed to find out the constraints faced by the maize cultivating farmers in production of maize were explained in terms of ranks and total mean (score). The results inferred that the most important constraint in cultivation of maize were high cost of seed, Infestations of pests and diseases especially fall armyworm, Severe drought condition or long dry spell, credit facility in time, High cost of fertilizers and plant protections, High labour wages, and the most important constraint in marketing of maize were price fluctuation, lack of remunerative price of the crop, Lack of public procurement on MSP. Suggestions opined were, initiatives of govt. procurement on MSP in peak harvesting period, Seed price policy by Govt, Appropriate Credit facility in time Crop insurance in drought and pest incidence, Timely supply of inputs and Reasonable input costs.

\section{Introduction}

Maize (Zea mays L.) is one of the most versatile emerging crops having wider adaptability under varied agro-climatic conditions. Globally, maize is known as 'Queen of Cereals' because it has the highest genetic yield potential among the cereals. Maize is considered a promising option for diversifying agriculture in upland areas of India. It now ranks as the third most important food grain crop in India. Maize is the third largest grain crop in India, after rice and wheat, it is cultivated on an area of 9.47 million hectares, has an annual production of 28.72 million tonnes, and an average national productivity of $30.32 \mathrm{~kg}$ per hectare (Directorate of Economics and Statistics Government of India Report 2017-18). It is grown during rainy (Kharif), winter (Rabi) and spring season, but major production is in the rainy season. The area under maize crop in Maharashtra state was 1.16 million hectares (12.21 percent), production of 3.54 million 
tonnnes (12.33 percent), with productivity of $3062 \mathrm{~kg}$ per hectare. An attempt had been made to study the constraints faced by the maize growers in production and marketing of maize in Marathwada Region of Maharashtra.. It had been proven beneficial to know constraint status of the growers in production and marketing to identify the challengers faced and suggestions to overcome these conditions. This in turn would help relevant stake holders to formulate appropriate policies which would give an added boost to the industry.

\section{Materials and Methods}

Multi stage sampling design was adopted for selection of districts, tahsils, villages and maize growers. In the first stage, two districts namely Aurangabad, and Jalna were purposely selected from Marathwada region as area and production of maize is concentrated in these districts. In the second stage, from each district two tahsils were selected on the basis of more area under maize cultivation. In third stage, list of predominant villages with respect to area under maize were obtained from selected tahsils. From each tahsils, three villages were selected purposely. In Aurangabad district the selected villages from Kannnad tahsils were namely Hatnur, Tapargaon and Nachanvell and from Sillod tahsil Modha (Bk), Andhari and Ghatnanadra were selected. In Jalna district from Bhokardhan tahsil Kedakheda, Javkhed and Annva villages were selected and from Jafrabad tahsil Khaparkheda, Khasgaon and Janephal villages were selected.

The list of maize growers for last one year was obtained from Gram Sewak and using simple random sampling technique, fifteen growers from each village were selected randomly. In this way, from two districts, one hundred eighty maize growers were selected for the present study. The data for the year 2019-20 was collected from maize growers with the help of pre-tested schedule through personal interview method.

\section{Garrett's ranking technique}

The constraints in maize production were analyzed using Garrett's ranking technique. The ranks given by each respondent were converted into per cent position by using formula:

$$
\text { Per cent position }=\frac{100 \times(\mathrm{Rij}-0.5)}{\mathrm{Nj}}
$$

Where,

Rij = Rank given to ith constraint by the jth individual and

$\mathrm{Nj}=$ Number of constraints ranked by the $\mathrm{jth}$ individual.

The estimated per cent positions were converted into scores using Garrett's table.

The mean score values estimated for each factor were arranged in the descending order. The constraint with the highest mean value was considered as the most important one and the others followed in that order.

\section{Results and Discussion}

Constraints and suggestions of maize growers in production and marketing of maize

Multiple responses taken to ascertain the constraints faced by the maize growers in production and marketing of maize.

Opinions of selected maize growers were taken in order to understand the problems in production and marketing. Thus suggestions of maize growers were recorded and analyzed (Fig. 1). 
Constraints faced by maize growers in production

Garrett's ranking technique was employed to find out the constraints faced by the maize cultivating farmers in production of maize were explained in terms of ranks and total mean (score) presented in Table 1. It shows how the percentage position of each rank was converted into scores using Garret's table. For each constraint, scores of individual respondents was added together and then divided by total number of respondents for whom scores was added. Thus, mean score for each constraint was ranked by arranging them in the descending order (Fig. 2).

Table.1 Garret's ranks and scores on Constraints encountered by growers in production of maize in Marathwada Region of Maharashtra State

\begin{tabular}{|c|l|c|c|}
\hline Sr. No & Constraint in production of maize & $\begin{array}{c}\text { Total mean } \\
\text { (Score })\end{array}$ & Rank \\
\hline $\mathbf{1}$ & Severe drought condition or long dry spell & 53.41 & III \\
\hline $\mathbf{2}$ & High cost of seed & 62.15 & I \\
\hline $\mathbf{3}$ & High cost of fertilizers and plant protections & 48.07 & V \\
\hline $\mathbf{4}$ & Non availability of credit facility in time & 50.79 & IV \\
\hline $\mathbf{5}$ & Infestations of pests and diseases especially fall & 62.01 & II \\
\hline & armyworm & 47.4 & VI \\
\hline $\mathbf{6}$ & High labour wages & 44.78 & VII \\
\hline $\mathbf{7}$ & Poor availability of quality seed materials & 44.68 & VIII \\
\hline $\mathbf{8}$ & Lack of technical guidance about mechanized farming & 42.04 & X \\
\hline $\mathbf{9}$ & Crop damaged by stray animals, wild animals & 43.31 & IX \\
\hline $\mathbf{1 0}$ & Depletion of soil fertility & & \\
\hline
\end{tabular}

Table.2 Garret's ranks and scores on Constraints encountered by farmers in marketing of maize in Marathwada Region of Maharashtra State

\begin{tabular}{|c|l|c|c|}
\hline $\begin{array}{l}\text { Sr. } \\
\text { No }\end{array}$ & Constraint in marketing of maize & $\begin{array}{l}\text { Total mean } \\
\text { (Score) }\end{array}$ & Rank \\
\hline $\mathbf{1}$ & Lack of remunerative price of the crop & 61.34 & II \\
\hline $\mathbf{2}$ & Lack of public procurement on MSP & 60.69 & III \\
\hline $\mathbf{3}$ & Price fluctuation & 63.46 & I \\
\hline $\mathbf{4}$ & High cost of transportation & 48.94 & V \\
\hline $\mathbf{5}$ & Deduction in payments by commission agent & 51.33 & IV \\
\hline $\mathbf{6}$ & Distress sale & 44.79 & VI \\
\hline $\mathbf{7}$ & Exploitative practices of intermediaries & 41.56 & VIII \\
\hline $\mathbf{8}$ & Market places are far away & 43.44 & VII \\
\hline $\mathbf{9}$ & Delayed cash payment from the traders & 40.77 & IX \\
\hline $\mathbf{1 0}$ & Malpractices in weighing & 38.69 & X \\
\hline
\end{tabular}


Table.3 Garret's ranks and scores on suggestions by growers in productions and marketing of maize in Marathwada Region of Maharashtra State

\begin{tabular}{|c|l|c|c|}
\hline $\begin{array}{c}\text { Sr. } \\
\text { No }\end{array}$ & $\begin{array}{l}\text { Suggestions in production and marketing of } \\
\text { maize }\end{array}$ & $\begin{array}{l}\text { Total mean } \\
\text { (Score) }\end{array}$ & Rank \\
\hline $\mathbf{1}$ & Seed price policy by Govt. & 58.04 & II \\
\hline $\mathbf{2}$ & Appropriate Credit facility in time & 57.24 & III \\
\hline $\mathbf{3}$ & Crop insurance in drought and pest incidence & 56.68 & IV \\
\hline $\mathbf{4}$ & Reasonable input costs & 54.08 & VI \\
\hline $\mathbf{5}$ & Timely supply of inputs & 54.36 & V \\
\hline $\mathbf{6}$ & $\begin{array}{l}\text { Initiatives of govt. procurement on MSP in peak } \\
\text { harvesting period }\end{array}$ & 59.61 & I \\
\hline
\end{tabular}

Fig.1 Constraints faced by maize growers in production

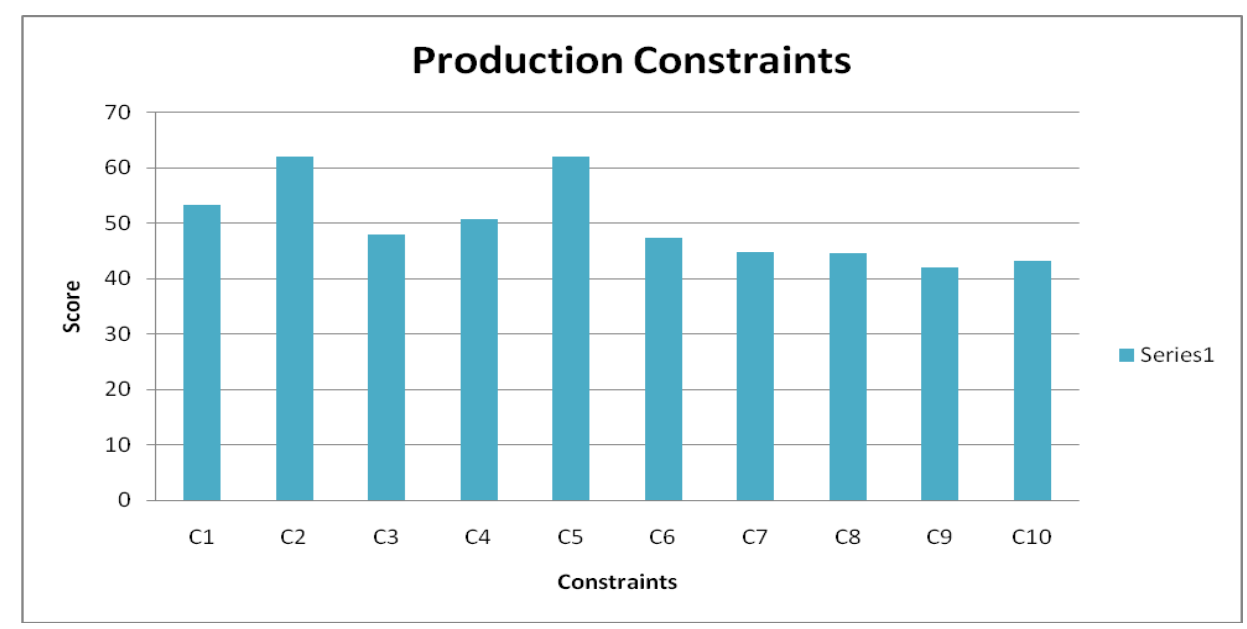

Fig.2 Constraints faced by maize growers in marketing

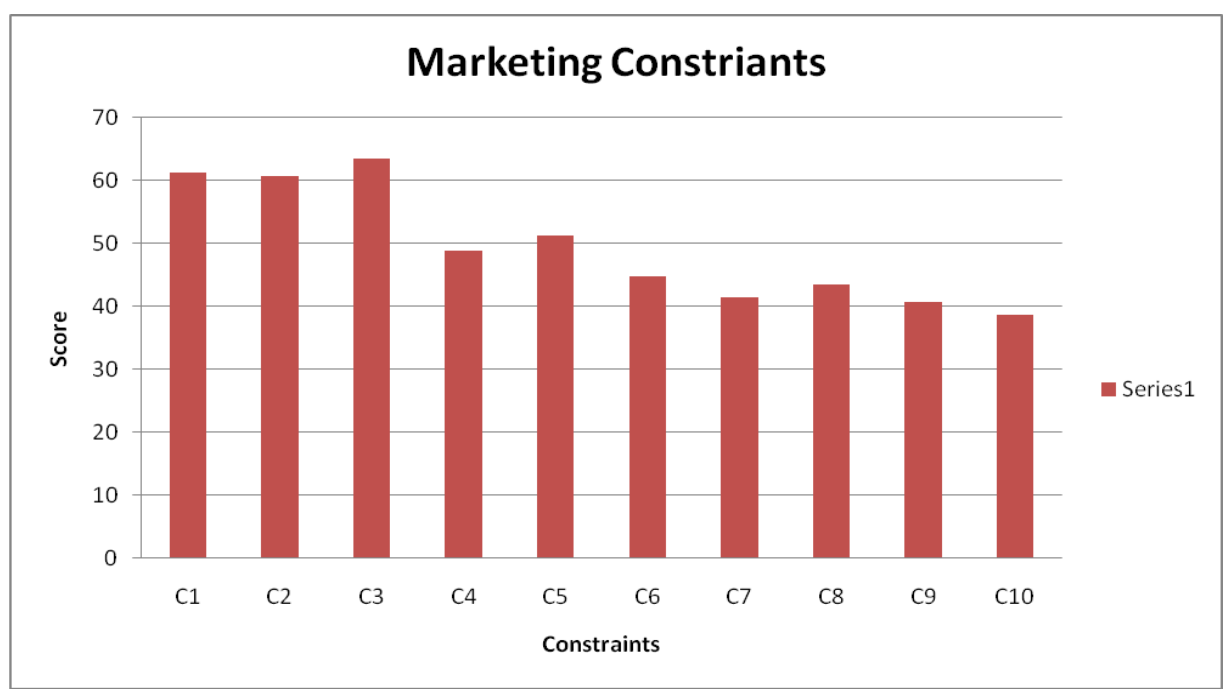


Fig.3 Suggestions given by maize growers in production and marketing

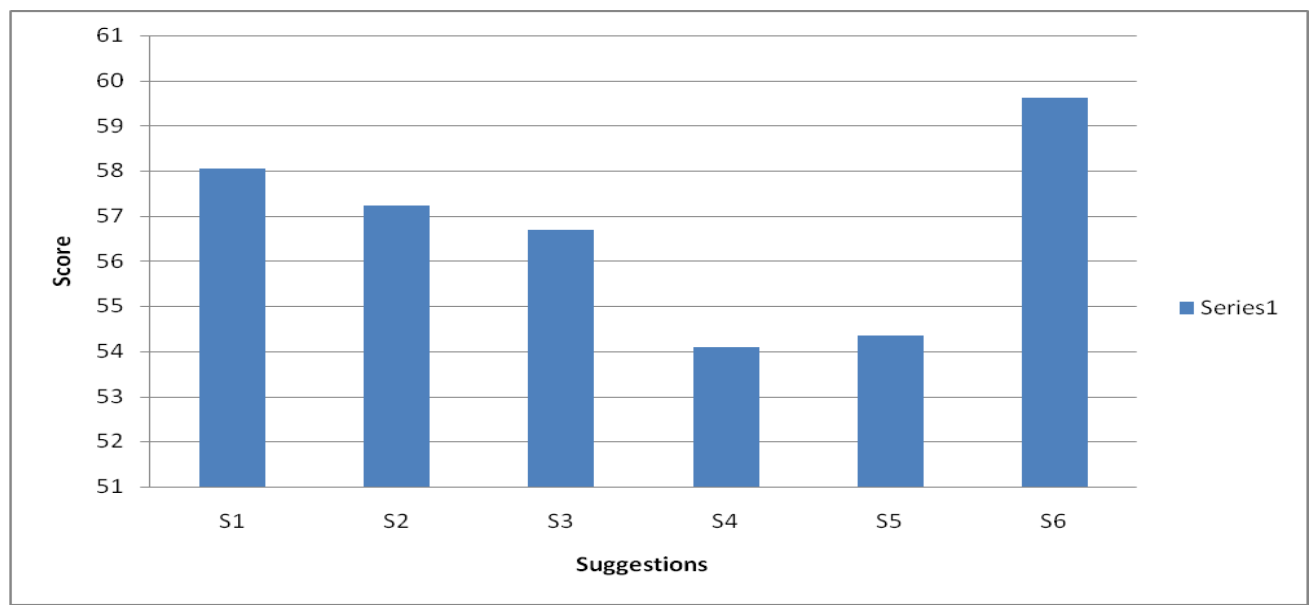

The results inferred that the most important constraint in cultivation of maize which rank first was high cost of seed with total mean score of 62.15 , followed by Infestations of pests and diseases especially fall armyworm and Severe drought condition or long dry spell which ranks II and III with total mean scores 62.01 and 53.41. The other constraints in production of maize were, non availability of credit facility in time (IV), High cost of fertilizers and plant protections (V), High labour wages (VI), Poor availability of quality seed materials (VII), Lack of technical guidance about mechanized farming (VIII), Depletion of soil fertility (IX) and Crop damaged by stray animals, wild animals (X) with total mean score of 50.79, 48.07, 47.40, 44.78, 44.68, 43.31 and 42.04 respectively. Gopala et al., 2012), Ranawat Yogita, et al., (2013) Choudhri Harendra Pratap Singh, et al., (2018) also revealed such constraints faced by the maize cultivating farmers in production of maize

\section{Constraints faced by maize growers in marketing}

Garrett's ranking technique was employed to find out the constraints faced by the maize cultivating farmers in marketing of maize were explained in terms of ranks and total mean (score) presented in Table 2 It shows how the percentage position of each rank was converted into scores using Garret's table. For each constraint, scores of individual respondents was added together and then divided by total number of respondents for whom scores was added. Thus, mean score for each constraint was ranked by arranging them in the descending order (Fig. 3).

The results inferred that the most important constraint in marketing of maize which rank first was price fluctuation with total mean score of 63.46, followed by lack of remunerative price of the crop and Lack of public procurement on MSP which ranks II and III with total mean scores 61.34 and 60.69. The other constraints in marketing of maize were, Deduction in payments by commission agent (IV), High cost of transportation (V), Distress sale (VI), Market places are far away (VII), Exploitative practices of intermediaries (VIII), Delayed cash payment from the traders (IX) and Malpractices in weighing (X) with total mean score of $51.33 ; 48.94$; $44.79 ; 43.44 ; 41.56 ; 40.77$; and 39.69 respectively. Chaval and Kataria (2010) Vadivelu and Kiran (2013), also revealed 
the most important constraint in marketing of maize

\section{Suggestions given by maize growers in production and marketing}

Suggestions opined by maize growers to overcome the constraints in production and marketing of maize were in terms of ranks and total mean score presented in Table 3 The results inferred with total mean score of 59.61 per cent the initiatives of govt. procurement on MSP in peak harvesting period rank I, followed by Seed price policy by Govt. (II), Appropriate Credit facility in time (III), Crop insurance in drought and pest incidence (IV), Timely supply of inputs (V) and Reasonable input costs (VI) with total mean score 58.04; 57.24; 56.68; 54.36 and 54.08 respectively. Bandi et al., (2020), Chahal and Kataria (2010) and Shakuntala Devi and Suhasini (2016) aslo inferred same suggestion opinioned by maize growers to overcome the constraints in production and marketing of maize.

\section{References}

Bandi Srikanth1, K .V. Deshmukh, R. V. Chavan and H.H. Kausadikar (2020). Constraints and Suggestions of Maize Production and Marketing in Telangana State. Ind. J. Pure App. Biosci. 8(1): 69-73

Chahal S.S and Poonam Kataria .2010. Constraints in the production and marketing of maize in Punjab . Agric. Update. 5(1 \&2): 228-236

Gopala Y M, B Krishnamurthy and T P Bharathkumar (2012). Production, Marketing and Storage Constraints of
Maize Growers in district Chick aballapur Karnataka. Research Journal of Agricultural Sciences, 3(4): 873-875

Harendra Pratap Singh Choudhri, GP Singh, Rajeev Singh, Punam Kushwaha, Ashutosh Kumar Ranjan, Mithlesh Kumar, Abhineet and Krishna Kumar.(2018) Constraints analysis of maize cultivation in Bahraich district of Uttar Pradesh. The Pharma Innovation Journal 7(2): 30-31

Ranawat Yogita, Mahadik R.P., Sisodia S.S. 2013.Problems Faced By Maize Growers of Udaipur District. Journal of Community Mobilization and Sustainable Development Vol: 8 (1): 84-89.

Ranawat Yogita and Hanuman Ram. 2015. Constraints encountered by the farmers in adoption of modern maize production techniques. Agriculture Update 10(1): 44-47.

Shakuntala Devi I. and K. Suhasini. 2016. Economics and constraint analysis of non traditional maize farmers in Mahbubnagar district under Tank of Andhra Pradesh. International Research Journal of Agricultural Economics and Statistics. 7(1): 232241

Yugraj Singh and Baljinder Kaur Sidana. (2019). Severity Analysis of Problems Faced by Maize Growers in Punjab. Economic Affairs, 64 (2): 317-322.

Vadivelu A. and Kiran B.R. 2013. Problems and Prospects of Agricultural Marketing In India: an Overview. International Journal of Agricultural and Food Science 3(3): 108-118.

\section{How to cite this article:}

Thombre, R. F., K. V. Deshmukh, S. S. More and Chavan, R. V. 2020. Constraint and Suggestion Analysis in Production and Marketing of Maize in Marathwada Region of Maharashtra using Garrett's Ranking Technique. Int.J.Curr.Microbiol.App.Sci. 9(08): 17731778. doi: https://doi.org/10.20546/ijcmas.2020.908.205 